\title{
Crustal thickness in Fennoscandia from phase velocities of Rayleigh waves
}

\author{
Eysteinn Tryggvason $(*)$ \\ Ricevuto il 7 Luglio 1961
}

\section{INTRODUCTION.}

It has been shown previously, that local variations in crustal thickness can be determined from phase velocities of Rayleigh waves over relatively dense nets of seismograph stations (Press 1956, Press 1957, Ewing and Press 1959). The method needs a net of stations with homogeneous instrumentation of vertical seismographs. This net must be sufficiently dense to allow identification of each individual wave crest at every station'inside the area under investigation. Furthermore, the method needs a dispersed train of Rayleigh waves of sufficiently large amplitudes to be clearly recorded by the seismographs used. The earthquake producing this wave train must be at a great distance from the area under investigation, and the wave path should be over homogeneous crustal structure to avoid disturbing interference.

In this paper an attempt is made to use the phase-velocity method to determine the thickness of the earth's crust in Fennoscandia. Two earthquakes are selected for this study, one with surface-wave propagation nearly perpendicular to the west coast of Norway, the other with wave propagation nearly parallel to this.

Methods aNd Materials USED.

Data about the earthquakes, selected for this study, are given in Table I. Table II gives the coordinates of the seismograph stations

(*) On leave from Vedurstofan, Reykjavik, Iceland. 
and the distances and directions to the epicenters, and Fig. 1 shows the station net.

Table I. - Earthquakes SElected For the Study (Gutenberg 1959 b and 1960) ( $M=$ Magnitude, $m=$ Unified magnitude).

\begin{tabular}{|c|c|c|c|c|c|c|}
\hline Date & $\operatorname{Tim} \theta$ & Location & Depth & $M$ & $m$ & \\
\hline 1957 July 28 & $\begin{array}{lll}08 & 40 & 05\end{array}$ & $16^{3} / 4 \mathrm{~N} 99 \mathrm{~W}$ & Normal & 7.9 & 7.0 & Mexico \\
\hline 1958 Nov. 6 & 225806 & $441 / 2 \mathrm{~N}^{2} 48^{3} / 4 \mathrm{E}$ & $75 \mathrm{~km}$ & 8.7 & 8.0 & Kurile Islands \\
\hline
\end{tabular}

At all stations the records of short-period vertical seismographs were used. The time of each wave crest was measured to the nearest second. If the amplitude was very small and the period large, the accuracy of the measurement was of the order of 5 sec, but for larger amplitudes, the accuracy was about 1 sec.

Table II. - Seismograph stations, distance and DiRection to the EPICENTERs ( $h=$ height of station above sea level, distance in degrees, azimuth in degrees clockwise from north).

\begin{tabular}{|c|c|c|c|c|c|c|c|c|}
\hline \multirow{2}{*}{\multicolumn{2}{|c|}{ Station }} & \multirow{2}{*}{$\begin{array}{l}\text { Latitude } \\
\text { North }\end{array}$} & \multirow{2}{*}{$\begin{array}{c}\text { Longitude } \\
\text { East }\end{array}$} & \multirow{2}{*}{$\begin{array}{c}h \\
\mathrm{~m}\end{array}$} & \multicolumn{2}{|c|}{$\begin{array}{c}\text { Mexico } \\
\text { earthquake }\end{array}$} & \multicolumn{2}{|c|}{$\begin{array}{l}\text { Kurile Islands } \\
\text { earthquake }\end{array}$} \\
\hline & & & & & Distance & Azimuth & Distance & Azimuth \\
\hline Goteborg & $(G b)$ & $57^{\circ} 42^{\prime}$ & $11^{\circ} 59^{\prime}$ & 66 & - & - & 72.0 & 30.9 \\
\hline Helsinki & $(\mathrm{Hel})$ & $60^{\circ} 10^{\prime}$ & $24^{\circ} 58^{\prime}$ & 20 & 91.1 & 307.3 & 66.0 & 39.7 \\
\hline Kiruna & $(K i)$ & $67^{\circ} 50^{\prime}$ & $20^{\circ} 25^{\prime}$ & 390 & 85.0 & 303.0 & 61.5 & 39.6 \\
\hline Köbenhavn & $(K o b)$ & $55^{\circ} 41^{\prime}$ & $12^{\circ} 26^{\prime}$ & 13 & 87.8 & 296.6 & 73.6 & 30.8 \\
\hline Lund & $(L u)$ & $55^{\circ} 42^{\prime}$ & $13^{\circ} 11^{\prime}$ & 32 & 88.2 & 297.3 & 一 & - \\
\hline Skalstugan & $(S k)$ & $63^{\circ} 35^{\prime}$ & $12^{\circ} 17^{\prime}$ & 580 & 84.2 & 296.1 & 66.9 & 32.3 \\
\hline Sodankylä & (Sod) & $67^{\circ} 22^{\prime}$ & $26^{\circ} 39^{\prime}$ & - & 87.3 & 308.7 & 60.2 & 44.1 \\
\hline Uppsala & $(U p)$ & $59^{\circ} 52^{\prime}$ & $17^{\circ} 38^{\prime}$ & 14 & 88.2 & 301.0 & 68.6 & 35.3 \\
\hline
\end{tabular}

To correct these observed arrival times $(t)$ for reading errors, they are compared with the number of the waves $(N)$, as Fig. 2 shows. If an observed point lies definitely off the smooth curve, it is corrected 
to lie on the smooth curve. The wave period $(T)$ is found from the slope of this curve.

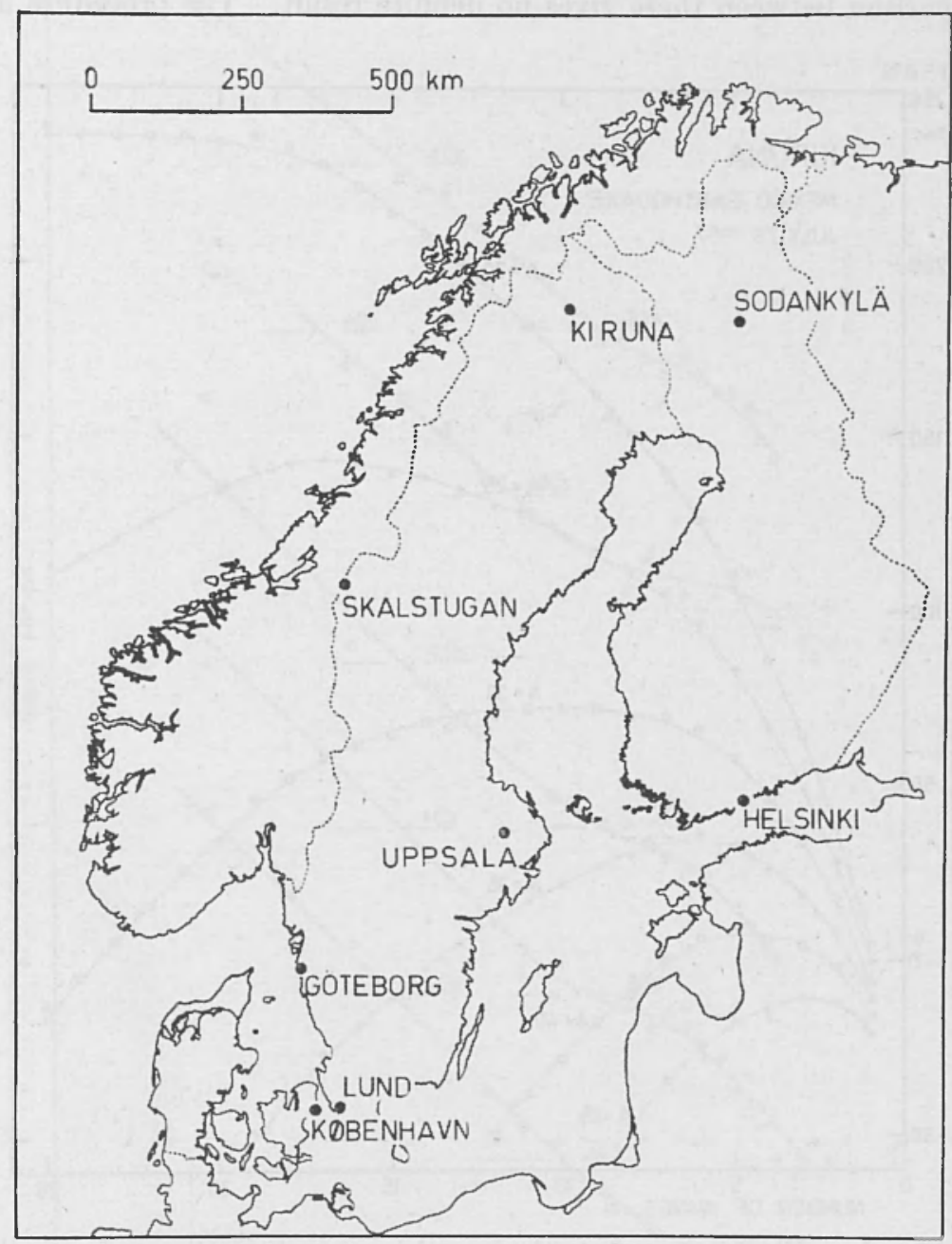

Fig. 1. - Locations of seismograph stations used in this study.

Another method for determining the wave period, used on the waves from the Mexico earthquake, is illustrated in Fig. 3. Here the observed period is plotted against $\log (N+2)$. The points thus obtained should lie on a smooth curve, which is almost a straight line for low values of $N$. 
The identification of the wave crests at different stations involves some problems. The seismograms look so different (Fig. 4) that direct comparison between these gives no definite result. The procedure used

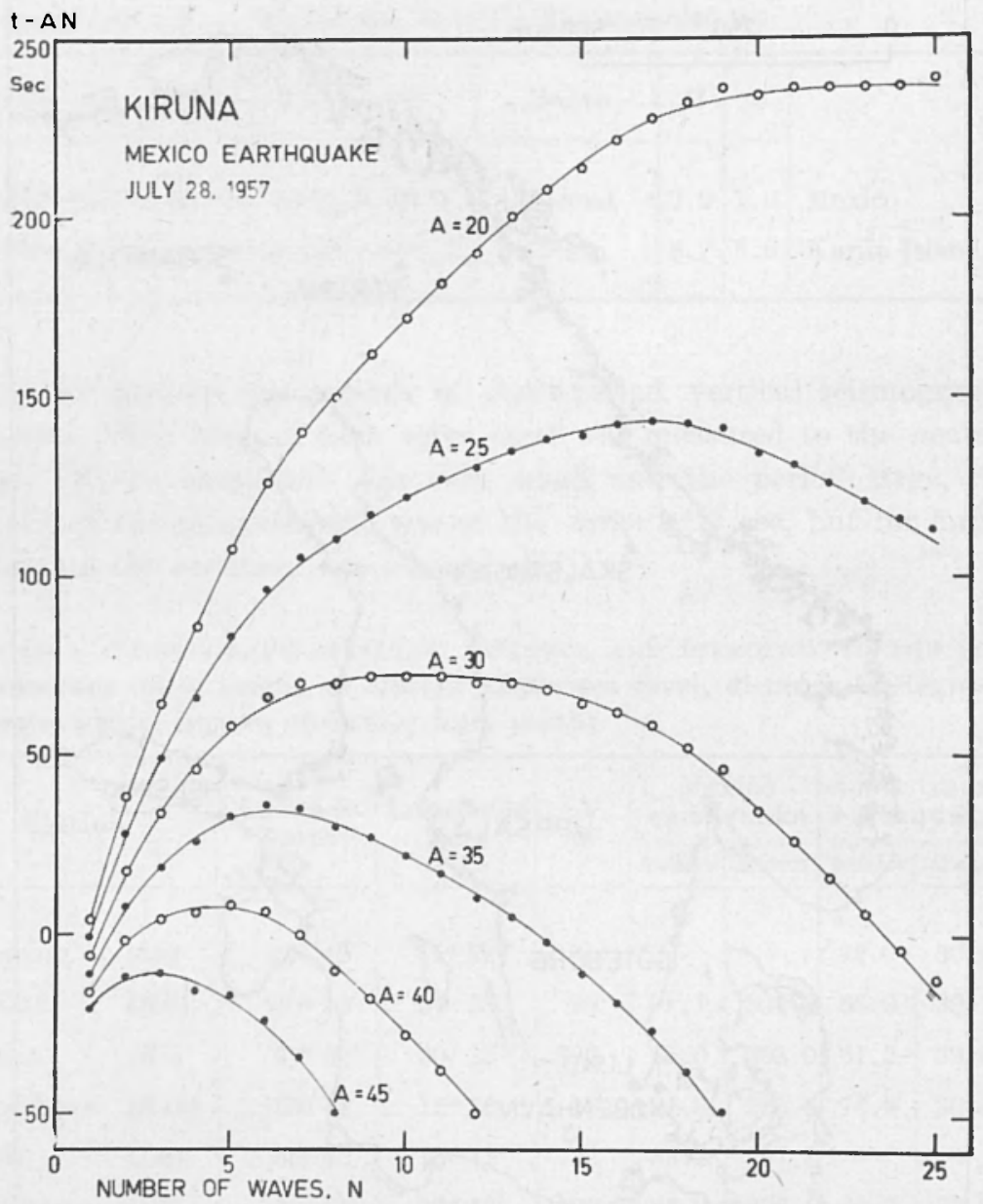

Fig. 2. - Illustration of method used in correcting observed arrival times and wave periods (see text).

is based on the assumption, that the direction of wave propagation is nearly along great circles through the epicenters, and that the phase velocities of the first observed Rayleigh waves in each earthquake are about $4 \mathrm{~km} / \mathrm{sec}$. This method gave only one possible solution for the first arrived waves, and it could also be used to determine the unknown 


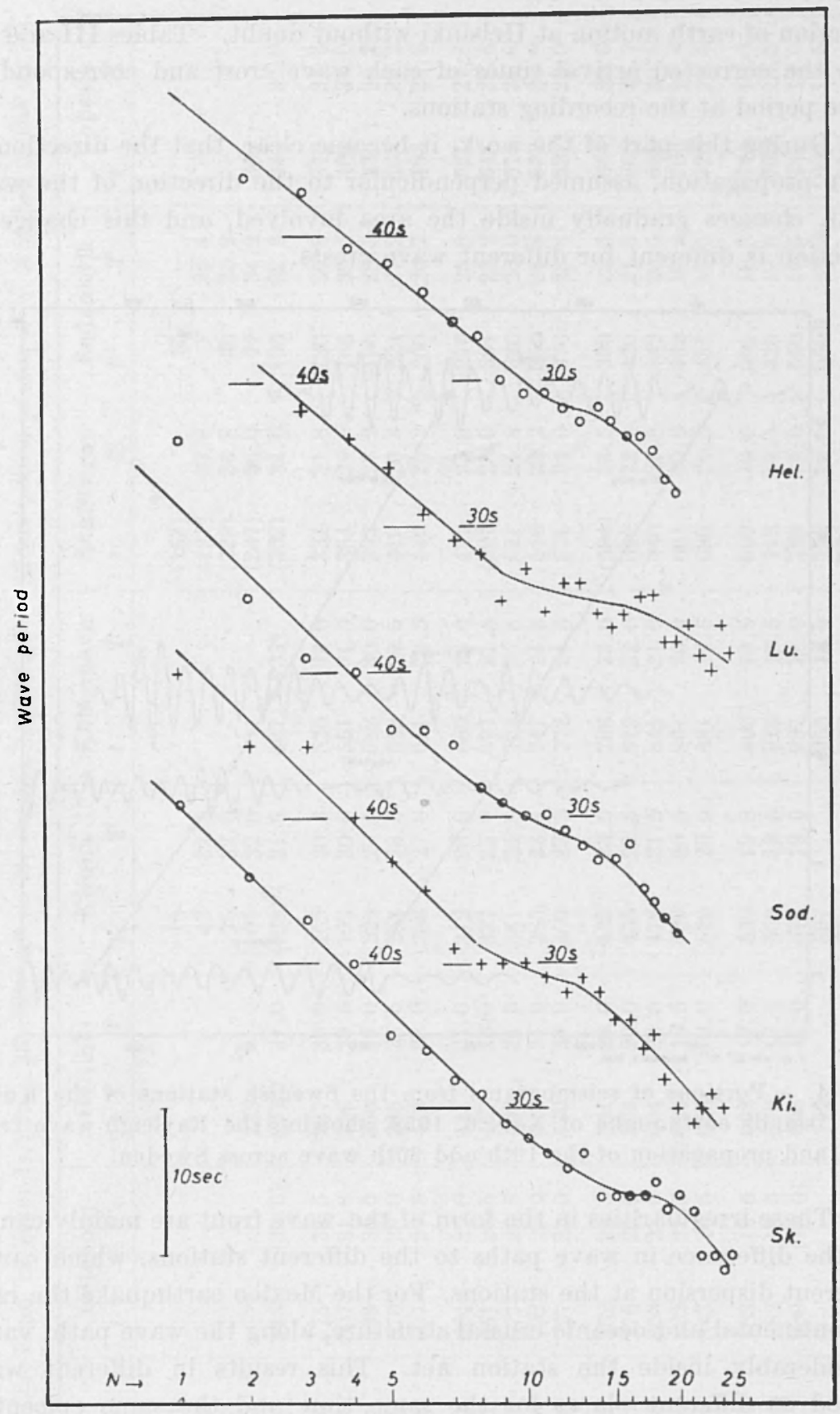

Number of waves

Fig. 3. - Illustration of method of correcting observed wave periods (see text). 
direction of earth motion at Helsinki without doubt. Tables III and IV give the corrected arrival times of each wave crest and corresponding wave period at the recording stations.

During this part of the work, it became clear, that the direction of wave propagation, assumed perpendicular to the direction of the wave front, changes gradually inside the area involved, and this change in direction is different for different wave crests.

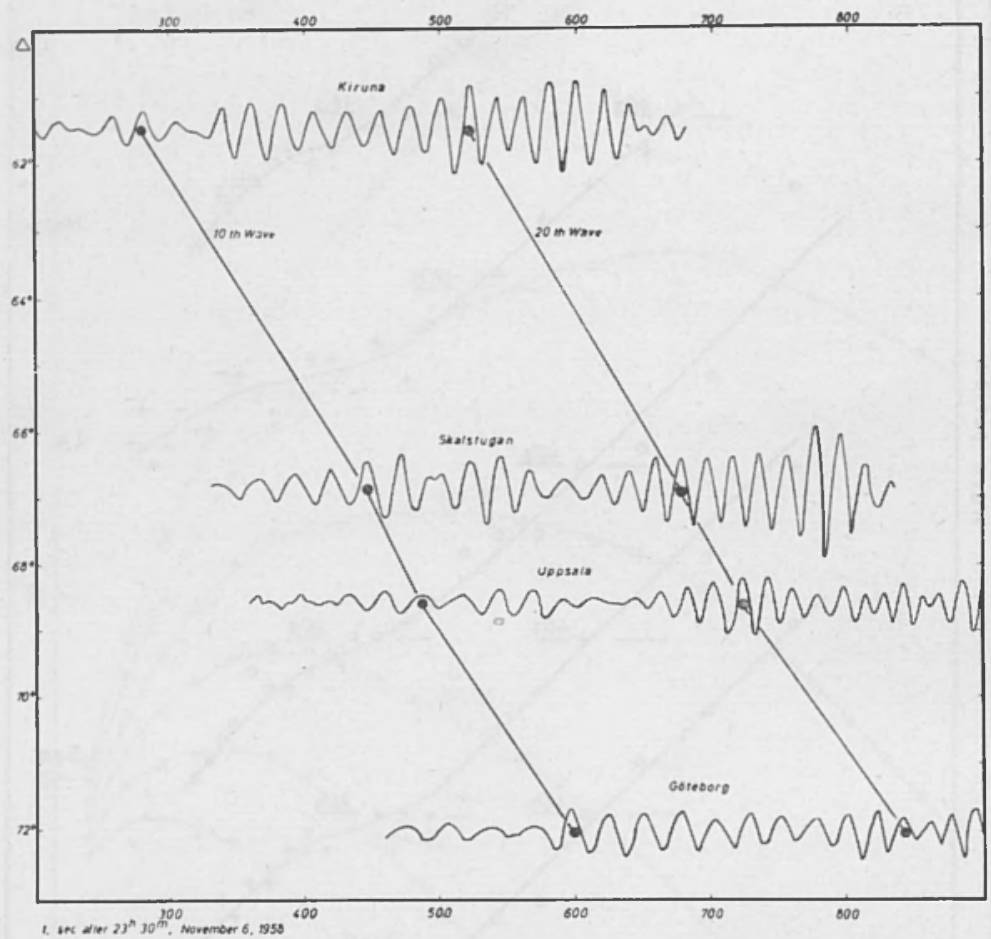

Fig. 4. - Portions of seismograms from the Swedish stations of the Kurile Islands earthquake of Nov. 6, 1958, showing the Rayleigh-wave train and propagation of the 10th and 20th wave across Sweden.

These irregularities in the form of the wave front are mainly caused by the difference in wave paths to the different stations, which causes different dispersion at the stations. For the Mexico earthquake the ratio of continental and oceanic crustal structure, along the wave path, varies considerably inside the station net. This results in different wave period at different places for the same time and the same epicentral distance. These circumstances obviously cause the wave front to change form and direction. 
Table IIt. - ARrival times of Rayleigh WAVe CRests From Kurile Islands earthqdake of Nov. 6, 1958 $\left(t=\right.$ Time in seconds after $23^{\mathrm{h}} 30^{\mathrm{m}} 00^{\mathrm{s}}$ on November 6,$1958 ; T=$ Wave period in sec; $N-$ Number of the wave).

\begin{tabular}{|c|c|c|c|c|c|c|c|c|c|c|c|c|c|c|}
\hline \multirow{2}{*}{$\mathrm{N}$} & \multicolumn{2}{|c|}{ Goteborg } & \multicolumn{2}{|c|}{ Helsinki } & \multicolumn{2}{|c|}{ Kiruna } & \multicolumn{2}{|c|}{ Kobenliavn } & \multicolumn{2}{|c|}{ Skalstugan } & \multicolumn{2}{|c|}{ Sodankylä } & \multicolumn{2}{|c|}{ Uppsala } \\
\hline & $t$ & $T$ & $t$ & $T$ & $t$ & $T$ & $t$ & $T$ & & $T$ & & $T$ & $t$ & $T$ \\
\hline $\begin{array}{l}1 \\
2 \\
3 \\
4 \\
5\end{array}$ & 443 & $(33.5)$ & $\begin{array}{l}235 \\
267\end{array}$ & 31.0 & $\begin{array}{r}10 \\
43 \\
75 \\
107 \\
(138)\end{array}$ & $\begin{array}{l}32.5 \\
32.0 \\
32.0 \\
31.5\end{array}$ & 487 & (33) & $\begin{array}{l}(153) \\
(191) \\
(229) \\
(267) \\
(302)\end{array}$ & $\begin{array}{l}37.8 \\
36.8 \\
36.0 \\
34.0\end{array}$ & $\begin{array}{r}-35 \\
1 \\
36 \\
72 \\
105\end{array}$ & $\begin{array}{l}35.8 \\
35.2 \\
34.2 \\
32.5\end{array}$ & $\begin{array}{l}309 \\
342\end{array}$ & 32.0 \\
\hline $\begin{array}{r}6 \\
7 \\
8 \\
9 \\
10\end{array}$ & $\begin{array}{l}475 \\
507 \\
539 \\
570 \\
597\end{array}$ & $\begin{array}{l}32.5 \\
31.8 \\
30.6 \\
29.0 \\
27.8\end{array}$ & $\begin{array}{l}297 \\
326 \\
356 \\
385 \\
413\end{array}$ & $\begin{array}{l}30.0 \\
29.5 \\
29.0 \\
28.5 \\
28.0\end{array}$ & $\begin{array}{l}169 \\
199 \\
229 \\
258 \\
286\end{array}$ & $\begin{array}{l}30.5 \\
30.0 \\
29.5 \\
28.5 \\
27.0\end{array}$ & $\begin{array}{l}520 \\
551 \\
582 \\
612 \\
641\end{array}$ & $\begin{array}{l}32.0 \\
31.0 \\
30.0 \\
29.5 \\
28.5\end{array}$ & $\begin{array}{l}334 \\
364 \\
392 \\
419 \\
446\end{array}$ & $\begin{array}{l}31.8 \\
29.0 \\
27.2 \\
26.8 \\
26.2\end{array}$ & $\begin{array}{l}136 \\
166 \\
196 \\
224 \\
250\end{array}$ & $\begin{array}{l}30.8 \\
29.5 \\
28.5 \\
27.2 \\
26.2\end{array}$ & $\begin{array}{l}373 \\
404 \\
435 \\
465 \\
493\end{array}$ & $\begin{array}{l}31.5 \\
31.0 \\
30.2 \\
29.2 \\
28.2\end{array}$ \\
\hline $\begin{array}{l}11 \\
12 \\
13 \\
14 \\
15\end{array}$ & $\begin{array}{l}624 \\
651 \\
677 \\
702 \\
727\end{array}$ & $\begin{array}{l}27.0 \\
26.5 \\
25.5 \\
25.0 \\
25.0\end{array}$ & $\begin{array}{l}441 \\
467 \\
492 \\
516 \\
539\end{array}$ & $\begin{array}{l}27.0 \\
26.0 \\
24.5 \\
24.0 \\
23.0\end{array}$ & $\begin{array}{l}312 \\
337 \\
361 \\
385 \\
409\end{array}$ & $\begin{array}{l}26.0 \\
25.0 \\
24.0 \\
23.8 \\
23.5\end{array}$ & $\begin{array}{l}669 \\
697 \\
722 \\
747 \\
772\end{array}$ & $\begin{array}{l}28.0 \\
27.5 \\
25.5 \\
24.5 \\
24.5\end{array}$ & $\begin{array}{c}471 \\
(497) \\
521 \\
546 \\
571\end{array}$ & $\begin{array}{l}25.5 \\
25.0 \\
24.8 \\
24.2 \\
24.0\end{array}$ & $\begin{array}{l}276 \\
301 \\
326 \\
350 \\
376\end{array}$ & $\begin{array}{l}25.8 \\
25.2 \\
25.0 \\
24.8 \\
23.8\end{array}$ & $\begin{array}{c}521 \\
548 \\
573 \\
597 \\
(621)\end{array}$ & $\begin{array}{l}27.8 \\
26.6 \\
24.8 \\
24.0 \\
23.0\end{array}$ \\
\hline $\begin{array}{l}16 \\
17 \\
18 \\
19 \\
20\end{array}$ & $\begin{array}{l}752 \\
776 \\
800 \\
822 \\
843\end{array}$ & $\begin{array}{l}24.5 \\
24.0 \\
23.0 \\
21.5 \\
20.5\end{array}$ & $\begin{array}{l}561 \\
584 \\
604 \\
624 \\
643\end{array}$ & $\begin{array}{l}23.0 \\
22.0 \\
20.0 \\
19.5 \\
19.0\end{array}$ & $\begin{array}{l}432 \\
455 \\
478 \\
499 \\
519\end{array}$ & $\begin{array}{l}23.0 \\
22.5 \\
21.5 \\
20.5 \\
20.0\end{array}$ & $\begin{array}{l}796 \\
819 \\
841 \\
861 \\
881\end{array}$ & $\begin{array}{l}23.0 \\
22.0 \\
21.0 \\
20.0 \\
19.5\end{array}$ & $\begin{array}{c}(594) \\
617 \\
640 \\
661 \\
680\end{array}$ & $\begin{array}{l}23.5 \\
22.8 \\
21.8 \\
20.0 \\
20.0\end{array}$ & $\begin{array}{l}399 \\
420 \\
442 \\
462 \\
481\end{array}$ & $\begin{array}{l}22.5 \\
21.5 \\
20.5 \\
19.8 \\
19.5\end{array}$ & $\begin{array}{c}(644) \\
665 \\
686 \\
706 \\
726\end{array}$ & $\begin{array}{l}22.0 \\
21.2 \\
20.5 \\
19.8 \\
19.5\end{array}$ \\
\hline $\begin{array}{l}21 \\
22 \\
23 \\
24 \\
25\end{array}$ & $\begin{array}{l}863 \\
882 \\
900\end{array}$ & $\begin{array}{c}19.5 \\
18.5 \\
(18.0)\end{array}$ & $\begin{array}{l}662 \\
679 \\
696 \\
712\end{array}$ & $\begin{array}{l}18.0 \\
17.5 \\
17.0\end{array}$ & $\begin{array}{l}539 \\
559 \\
578 \\
597 \\
616\end{array}$ & $\begin{array}{l}19.8 \\
19.5 \\
19.0\end{array}$ & $\begin{array}{l}900 \\
919 \\
937 \\
955 \\
973\end{array}$ & $\begin{array}{l}19.0 \\
18.5 \\
18.0 \\
18.0\end{array}$ & $\begin{array}{l}699 \\
718 \\
738 \\
758 \\
778\end{array}$ & $\begin{array}{l}19.5 \\
19.5 \\
19.0 \\
19.0\end{array}$ & $\begin{array}{l}501 \\
520 \\
540 \\
560\end{array}$ & $\begin{array}{l}19.5 \\
19.5 \\
19.5 \\
19.5\end{array}$ & $\begin{array}{l}745 \\
763 \\
781 \\
800 \\
816\end{array}$ & $\begin{array}{l}19.0 \\
18.5 \\
18.0 \\
17.5\end{array}$ \\
\hline
\end{tabular}


The direction of the wave front is found for each station triangle, where the wave velocity is computed. The arrival times of a wave front at the three stations I, II and III are $t_{1}, t_{2}$ and $t_{3}$ (Fig. 5). The

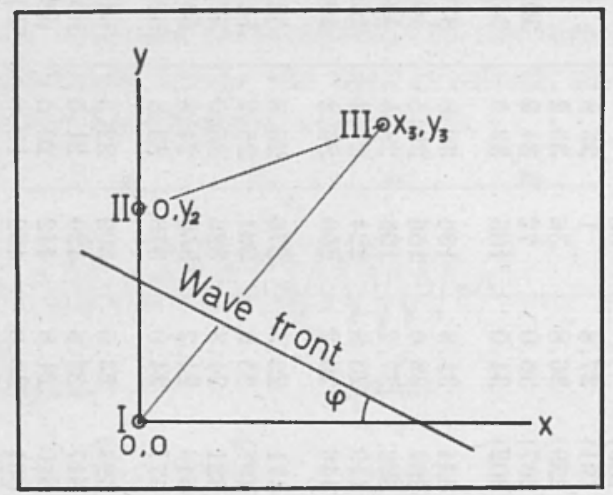

Fig. 5. - Geometry of plane wave front traversing station triangle.

equations giving apparent phase velocity $c$ and direction of wave propagation $\varphi$ inside the triangle, assuming a plane wave front are:

$$
\begin{aligned}
& \tan \varphi=\frac{y_{3}}{x_{3}}-\frac{y_{2}\left(t_{3}-t_{1}\right)}{x_{3}\left(t_{2}-t_{1}\right)} \\
& c=\frac{y_{2} \cos \varphi}{t_{2}-t_{1}}
\end{aligned}
$$

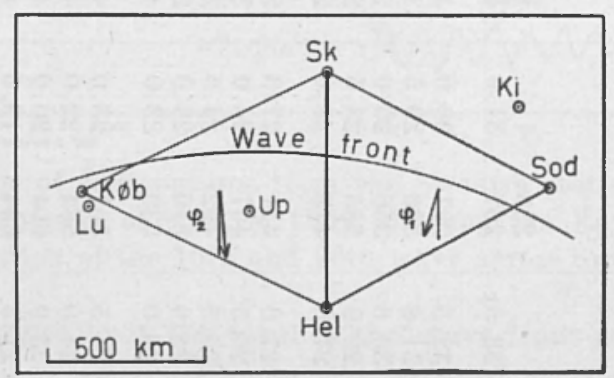

Fig. 6. - Geometry of curved wave front traversing the station net from the west (Mexico earthquake).

The value of $\varphi$ was found to vary ratrer regularly inside the area. This indicated a possibility of including the curvature of the wave front in the velocity computation, by assuming a simple smooth form of the 
Table IV. - Arrival times of Rayleigh wave crests from Mexico earthquake of July $28,1957(t=$ Time in seconds after $09^{\mathrm{h}} 20^{\mathrm{m}} 00^{\mathrm{s}}$ on July 28,$1957 ; T=$ Wave period in sec.; $N=$ Number of the wave).

\begin{tabular}{|c|c|c|c|c|c|c|c|c|c|c|c|c|c|c|}
\hline \multirow{2}{*}{$\mathrm{N}$} & \multicolumn{2}{|c|}{ Helsinki } & \multicolumn{2}{|c|}{ Kiruna } & \multicolumn{2}{|c|}{ Köbenlavn } & \multicolumn{2}{|c|}{ Lund } & \multicolumn{2}{|c|}{ Skalstugan } & \multicolumn{2}{|c|}{ Sodankyla } & \multicolumn{2}{|c|}{ Uppsala } \\
\hline & $t$ & $T$ & & $T$ & & $T$ & $t$ & $T$ & & $T$ & $t$ & $T$ & $t$ & $T$ \\
\hline $\begin{array}{l}1 \\
2 \\
3 \\
4 \\
5\end{array}$ & $\begin{array}{l}257 \\
301 \\
344 \\
383\end{array}$ & $\begin{array}{l}(48) \\
44.0 \\
41.0 \\
38.6\end{array}$ & $\begin{array}{r}28 \\
78 \\
123 \\
168 \\
208\end{array}$ & $\begin{array}{l}48.0 \\
44.8 \\
41.1 \\
38.3\end{array}$ & $\begin{array}{l}130 \\
171 \\
210 \\
246 \\
282\end{array}$ & $\begin{array}{l}43.6 \\
39.9 \\
36.7 \\
34.2\end{array}$ & $\begin{array}{l}220 \\
258 \\
294\end{array}$ & $\begin{array}{l}40.0 \\
37.0 \\
34.4\end{array}$ & $\begin{array}{r}14 \\
65 \\
111 \\
154 \\
194\end{array}$ & $\begin{array}{l}48.4 \\
44.1 \\
40.6 \\
37.8\end{array}$ & $\begin{array}{r}86 \\
142 \\
187 \\
228 \\
268\end{array}$ & $\begin{array}{l}49.2 \\
44.9 \\
41.3 \\
38.4\end{array}$ & $\begin{array}{l}178 \\
225 \\
267 \\
306\end{array}$ & $\begin{array}{l}(48) \\
43.8 \\
40.5 \\
37.8\end{array}$ \\
\hline $\begin{array}{r}6 \\
7 \\
8 \\
9 \\
10\end{array}$ & $\begin{array}{l}421 \\
457 \\
491 \\
524 \\
554\end{array}$ & $\begin{array}{l}36.4 \\
34.8 \\
33.2 \\
31.8 \\
30.4\end{array}$ & $\begin{array}{l}245 \\
280 \\
311 \\
341 \\
371\end{array}$ & $\begin{array}{l}35.8 \\
33.6 \\
31.7 \\
30.6 \\
29.9\end{array}$ & $\begin{array}{l}317 \\
348 \\
375 \\
402 \\
429\end{array}$ & $\begin{array}{l}32.1 \\
30.2 \\
28.4 \\
27.5 \\
26.3\end{array}$ & $\begin{array}{l}328 \\
359 \\
388 \\
416 \\
441\end{array}$ & $\begin{array}{l}32.3 \\
30.4 \\
28.7 \\
27.3 \\
26.4\end{array}$ & $\begin{array}{l}229 \\
263 \\
295 \\
326 \\
355\end{array}$ & $\begin{array}{l}35.4 \\
33.2 \\
31.6 \\
30.0 \\
28.6\end{array}$ & $\begin{array}{l}304 \\
340 \\
375 \\
407 \\
438\end{array}$ & $\begin{array}{l}36.2 \\
34.3 \\
32.7 \\
31.4 \\
30.5\end{array}$ & $\begin{array}{l}340 \\
374 \\
406 \\
437 \\
465\end{array}$ & $\begin{array}{c}35.4 \\
33.4 \\
31.6 \\
29.8 \\
(27.7)\end{array}$ \\
\hline $\begin{array}{l}11 \\
12 \\
13 \\
14 \\
15\end{array}$ & $\begin{array}{l}583 \\
612 \\
640 \\
667 \\
695\end{array}$ & $\begin{array}{l}29.4 \\
28.5 \\
28.0 \\
27.7 \\
27.2\end{array}$ & $\begin{array}{l}401 \\
430 \\
458 \\
487 \\
515\end{array}$ & $\begin{array}{l}29.3 \\
28.8 \\
28.4 \\
27.9 \\
27.0\end{array}$ & $\begin{array}{l}454 \\
480 \\
505 \\
530 \\
554\end{array}$ & $\begin{array}{l}25.7 \\
25.2 \\
24.8 \\
24.6 \\
24.5\end{array}$ & $\begin{array}{l}468 \\
492 \\
518 \\
544 \\
568\end{array}$ & $\begin{array}{l}25.8 \\
25.3 \\
25.1 \\
24.9 \\
24.6\end{array}$ & $\begin{array}{c}383 \\
410 \\
436 \\
463 \\
(487)\end{array}$ & $\begin{array}{l}27.6 \\
26.6 \\
25.8 \\
25.3 \\
24.6\end{array}$ & $\begin{array}{l}468 \\
498 \\
527 \\
555 \\
582\end{array}$ & $\begin{array}{l}29.7 \\
29.0 \\
28.4 \\
28.0 \\
27.6\end{array}$ & & \\
\hline $\begin{array}{l}16 \\
17 \\
18 \\
19 \\
20\end{array}$ & $\begin{array}{l}722 \\
748 \\
774 \\
799 \\
821\end{array}$ & $\begin{array}{l}26.6 \\
25.8 \\
24.8 \\
23.8 \\
22.8\end{array}$ & $\begin{array}{l}541 \\
567 \\
591 \\
614 \\
636\end{array}$ & $\begin{array}{l}26.0 \\
25.0 \\
24.2 \\
23.4 \\
22.4\end{array}$ & $\begin{array}{l}578 \\
602 \\
626 \\
651 \\
675\end{array}$ & $\begin{array}{l}24.3 \\
24.1 \\
23.9 \\
23.6 \\
23.3\end{array}$ & $\begin{array}{c}591 \\
615 \\
640 \\
665 \\
(687)\end{array}$ & $\begin{array}{l}24.4 \\
24.1 \\
23.8 \\
23.5 \\
23.1\end{array}$ & $\begin{array}{c}(511) \\
(535) \\
(559) \\
584 \\
607\end{array}$ & $\begin{array}{l}24.3 \\
24.1 \\
24.0 \\
23.9 \\
23.5\end{array}$ & $\begin{array}{l}609 \\
637 \\
662 \\
686 \\
709\end{array}$ & $\begin{array}{l}27.0 \\
26.0 \\
25.0 \\
23.9 \\
22.7\end{array}$ & $\begin{array}{l}673 \\
696 \\
717\end{array}$ & $\begin{array}{l}(22.5) \\
(22.0) \\
(22.0)\end{array}$ \\
\hline $\begin{array}{l}21 \\
22 \\
23 \\
24 \\
25 \\
26\end{array}$ & 843 & $(22.0)$ & $\begin{array}{l}656 \\
675 \\
695 \\
716 \\
736\end{array}$ & $\begin{array}{l}21.4 \\
20.6 \\
19.8 \\
19.0\end{array}$ & $\begin{array}{l}697 \\
719 \\
742 \\
763 \\
785 \\
804\end{array}$ & $\begin{array}{l}22.8 \\
22.4 \\
21.9 \\
21.5 \\
21.0\end{array}$ & $\begin{array}{l}709 \\
732 \\
753 \\
773 \\
796 \\
817\end{array}$ & $\begin{array}{l}22.6 \\
22.1 \\
21.7 \\
21.4 \\
21.0\end{array}$ & $\begin{array}{l}631 \\
654 \\
674 \\
694 \\
713 \\
733\end{array}$ & $\begin{array}{l}22.6 \\
21.6 \\
20.8 \\
20.0 \\
19.4\end{array}$ & 731 & & $\begin{array}{c}739 \\
761 \\
783\end{array}$ & $\begin{array}{l}(21.5) \\
(21.5) \\
(21.5)\end{array}$ \\
\hline
\end{tabular}


wave front. The form chosen is constant curvature for each wave front, where the center of curvature moves with the wave front in direction of the great circle through the epicenter and central Scandinavia.

The curvature was computed by different methods for the two earthquakes.

In case of the Mexico earthquake, the direction of the wave front was found by using equation [1] on the two large station triangles

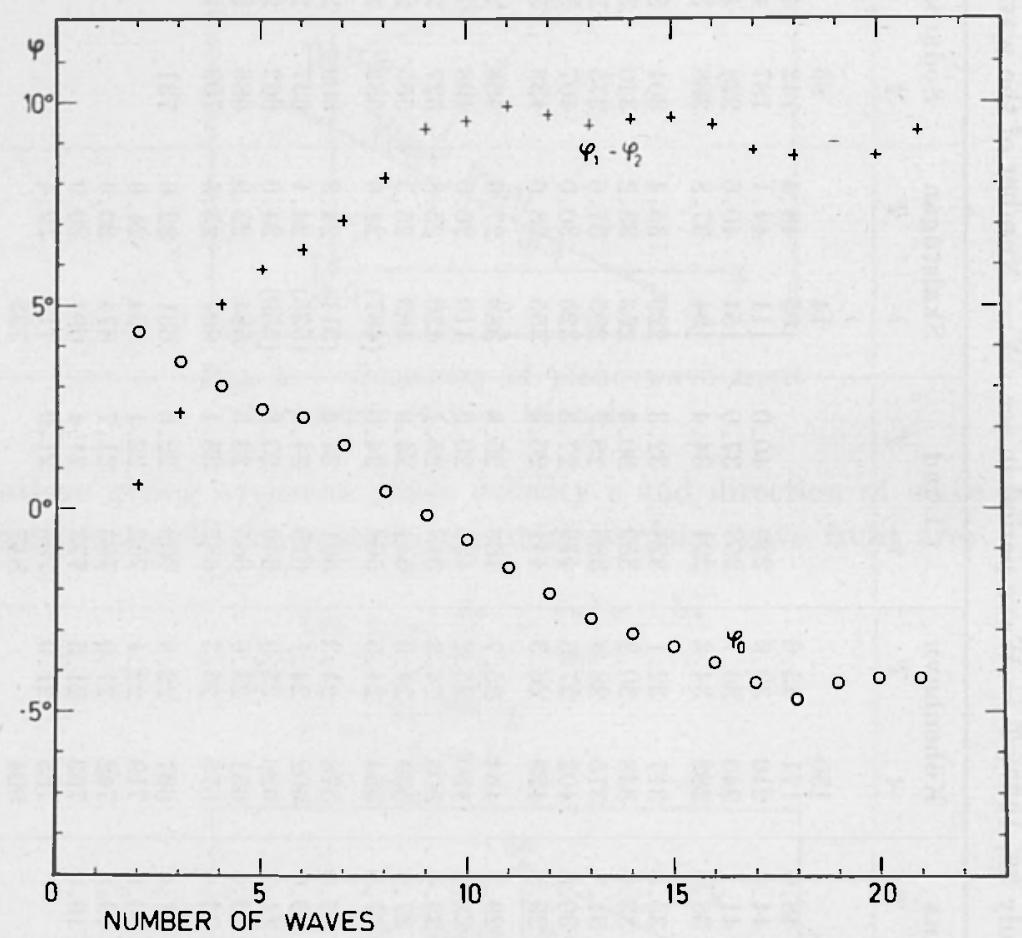

Fig. 7. - Observed direction of wave propagation of the Mexico earthquake in degrees from the line Helsinki-Skalstugan (see text).

Hel-Sk-Sod and Hel-Sk-Köb (Fig. 6). The directions $\varphi_{1}$, and $\varphi_{2}$ thus found were assumed to represent correct directions of wave propagation on lines parallel to the line $H e l-S k$ and halfways between this and $S o d$. and $K o b$ respectively.

Our assumptions make the direction of each wave front to depend only on the distance $x$ from the line Hel-Sk and the direction $\varphi_{0}$ on this line. The equation used to find approximate values of $\varphi$ is:

$$
\varphi=\varphi_{0}+\frac{2 x}{I}\left(\varphi_{1}-\psi_{2}\right)
$$


where $\varphi_{0}$ is the value of $\varphi$ on the line $H e l-S k$, and $L$ is the distance between Köbenhavn and Sodankylä.

The values of $\varphi_{0}$ and $\varphi_{1}-\varphi_{2}$ are shown in Fig. $\tau$.

The method used to compute the curvature of wave fronts of the Kurile Islands earthquake is illustrated in Fig. 8. The apparent phase velocity $c_{0}$ along the line $S o d-G b$ is found for each wave. The lines $S k-A$ and $H e l-B$ are parallel to the line $S o d-G b$. A circle through $A$,

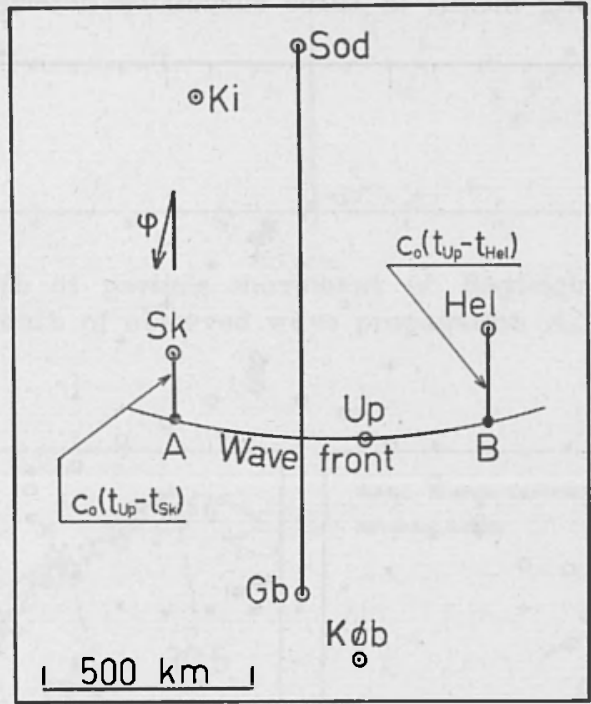

Fig. 8. - Geometry of curved wave front traversing the station net from the north (Kurile Islands earthquake).

$U p$ and $B$ is assumed to represent the true form of the wave front and the centers of these circles are assumed to move with the velocity $c_{0}$ along lines parallel to $S o d-G b$. The values of $\varphi_{0}, \varphi_{S k}$ and $\varphi_{H e l}$ are shown in Fig. 9. $\varphi_{0}$ gives the direction of the wave propagation on the line $S o d-G b$.

Direction of approach of Rayleigh waves from the Mexico EARTHQUAKE, AS INDICATED BY RECORDS OF LONG-PERIOD SEISMOGRAPHS AT UPPSALA AND KIRUNA.

The records of long-period seismographs at Uppsala and Kiruna were used to determine the apparent direction of particle movement 
of the surface waves recorded by the sliort-period vertical seismometers at these stations. At Uppsala, records of the long-period Benioff seismometers were used, and at Kiruna those of Galitzin seismometers.

The azimuth of particle movement is computed for every readable wave maximum or minimum. The values found $\left(A_{p}\right)$ are given in Fig. 10 together with the azimuths of wave propagation $\left(A_{i}\right)$ found by the method of correlation between stations. The values of $A_{p}$ are smoothed by taking means of three successive determinations.

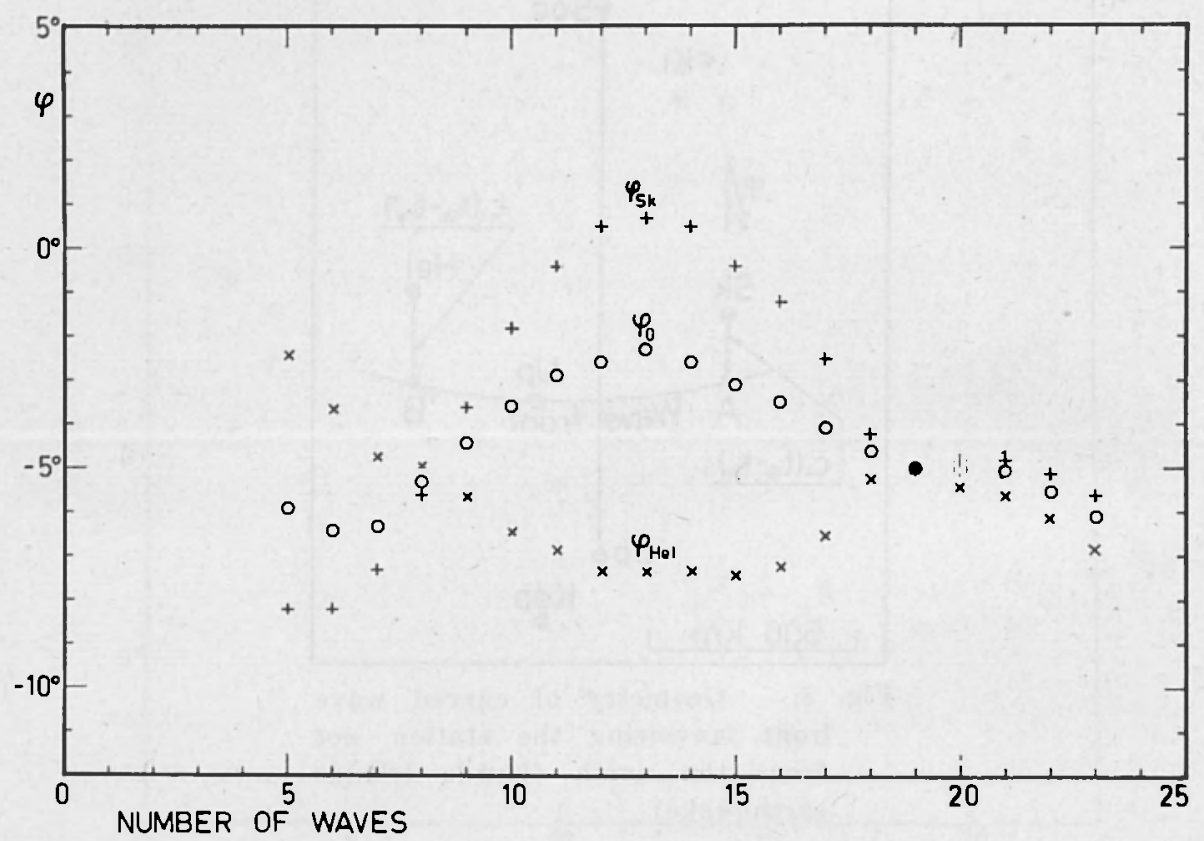

Fig. 9. - Observed direction of wave propagation of the Kurile Islands earthquake in degrees from the line Göteborg-Sodankyla (see text).

Fig. 10 shows a significant difference between $A_{p}$ and $A_{t}$ at both stations. This indicates a very irregular form of the wave front, or else the observed particle movements are not perpendicular to the wave front. Such effects can possibly be caused by irregularities in the geological structure near the stations. Moreover, the local geological structure may affect the seismometers to respond differently in different directions. Another possible cause of error in computed azimuths of particle movement is the use of incorrect instrumental constants. In our case, however, these constants are known relatively exact. A mixture of Love waves in the Rayleigh-wave train may influence the result of $A_{p}$, but 


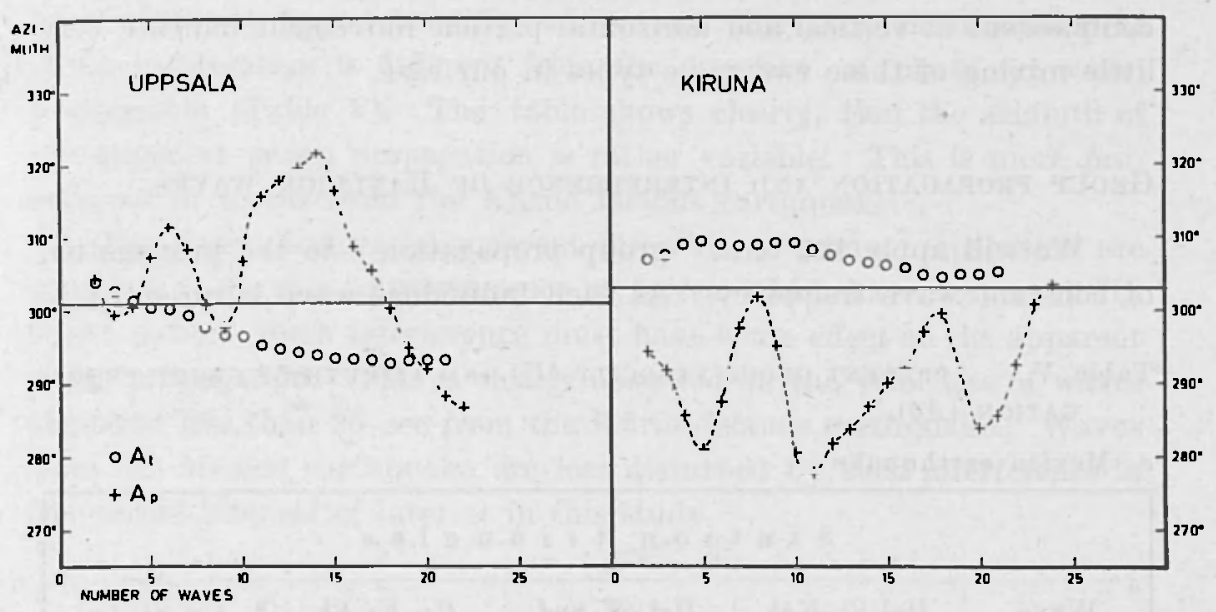

Fig. 10. - Azimuth of particle movement of Rayleigh waves (smoothed) $A_{p}$ and azimuth of observed wave propagation $A_{i}$.
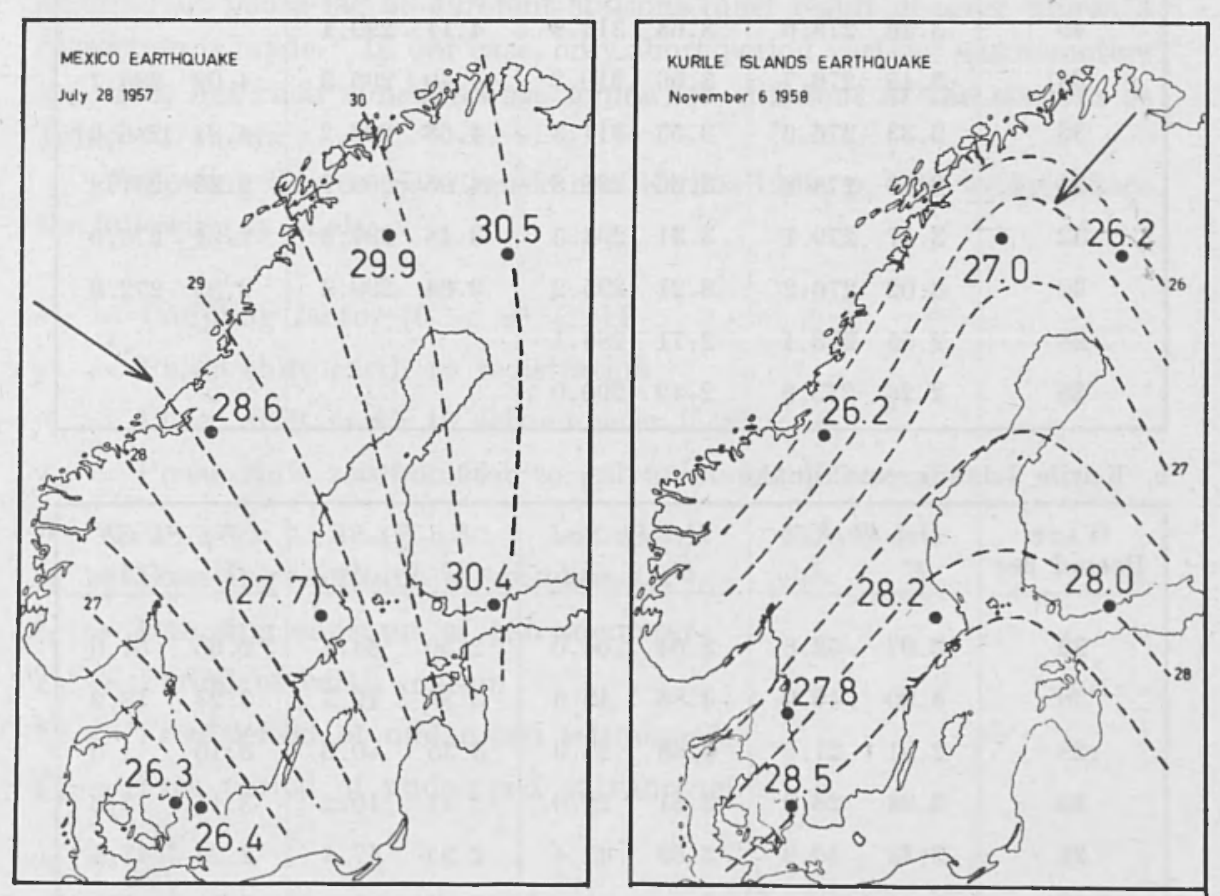

Fig. 11. - Period of tenth wave of the Mexico earthquake and Kurile Islands earthquake. The arrows show directions of great circles through the epicenters. 
comparisons of vertical and horizontal particle movement indicate very little mixing of these two wave types in our case.

Group PROPAGATION AND INTERFERENCE OF RAYLEIGH WAVES.

We will apply the term "group propagation" to the propagation of constant wave frequency. As each individual wave is observed to Table V. - Apparent group velocity $(U)$ and azinuth of group propaGATION $(A g)$.

a. Mexico earthquake

\begin{tabular}{|c|c|c|c|c|c|c|c|c|}
\hline \multicolumn{9}{|c|}{ Station triangles } \\
\hline \multirow{2}{*}{$\begin{array}{c}\text { Wave } \\
\text { Period sec }\end{array}$} & \multicolumn{2}{|c|}{$H e l-S k-I K o b$} & \multicolumn{2}{|c|}{ Hel-Sk-Sod } & \multicolumn{2}{|c|}{$U p-K i-S k$} & \multicolumn{2}{|c|}{$U p-S k-L u$} \\
\hline & $U$ & $A g$ & $U$ & $A g$ & & $A g$ & & $A g$ \\
\hline 44 & & & 3.41 & 303.6 & 3.02 & 297.6 & & \\
\hline 42 & 3.39 & 281.7 & 3.50 & 308.1 & 3.46 & 297.3 & & \\
\hline 40 & 3.49 & 278.6 & 3.65 & 310.8 & 4.11 & 299.1 & & \\
\hline 38 & 3.45 & 276.7 & 3.66 & 310.2 & 4.40 & 295.3 & 4.08 & 286.7 \\
\hline 36 & 3.33 & 276.6 & 3.53 & 311.3 & 4.58 & 299.2 & 4.04 & 286.0 \\
\hline 34 & 3.19 & 278.6 & 3.36 & 298.8 & 4.05 & 298.7 & 3.36 & 281.8 \\
\hline 32 & 3.17 & 279.1 & 3.31 & 294.5 & 3.48 & 297.8 & 2.61 & 275.9 \\
\hline 30 & 3.02 & 276.2 & 3.21 & 295.2 & 3.64 & 299.3 & 2.53 & 272.9 \\
\hline 28 & 2.55 & 273.1 & 2.71 & 288.1 & & & & \\
\hline 26 & 2.26 & 273.6 & 2.42 & 290.0 & & & & \\
\hline
\end{tabular}

b. Kurile Islands earthquake

\begin{tabular}{|c|c|c|c|c|c|c|c|c|}
\hline \multirow{2}{*}{$\begin{array}{l}\text { Wave } \\
\text { Period sec }\end{array}$} & \multicolumn{2}{|c|}{$H e l-S k-K \bar{o} b$} & \multicolumn{2}{|c|}{ Hel-Sk-Sod } & \multicolumn{2}{|c|}{$U p-K i-S k$} & \multicolumn{2}{|c|}{$U p-S k-G b$} \\
\hline & $U$ & $A g$ & $U$ & $A g$ & $U$ & $A g$ & $U$ & $A g$ \\
\hline 32 & 2.97 & 52.8 & 3.64 & 64.0 & 2.50 & 54.1 & 2.56 & 51.6 \\
\hline 30 & 3.00 & 40.0 & 3.85 & 48.6 & 3.39 & 19.7 & 3.27 & 18.9 \\
\hline 28 & 2.91 & 21.5 & 3.68 & 24.9 & 3.35 & -0.6 & 3.16 & 1.9 \\
\hline 26 & 2.98 & 23.8 & 3.61 & 28.0 & 3.41 & 10.2 & 3.11 & 13.3 \\
\hline 24 & 3.33 & 40.9 & 3. 69 & 47.4 & 2.95 & 47.4 & 2.26 & 47.4 \\
\hline 22 & 3.59 & 45.0 & 3.46 & 49.4 & 3.42 & 52.2 & 2.38 & 52.1 \\
\hline 20 & 3.65 & 45.6 & 3.39 & 49.3 & 3.65 & 47.9 & 2.71 & 48.0 \\
\hline
\end{tabular}


be of different period at different stations (Fig. 11), the direction of group propagation is different from the direction of phase (or wave) propagation (Table V). The table shows clearly, that the azimuth of the apparent group propagation is rather variable. This is more pronounced in waves from the Kurile Islands earthquake.

The great changes in apparent direction of group propagation are supposed to be due to interference of waves, which have traversed different paths. Such interference must have some effect on the apparent phase propagation. This is clearly observed on the velocities of waves of period less than 25 sec from the Kurile Islands earthquake. Waves from the Mexico earthquake are less disturbed by such interference in the period interval of interest in this study.

\section{Phase SHIFT EARTH-SEISMOGRaM.}

The method used here depends on the type of seismometers used, as different phase lag at different stations must result in error unless a correction is made. In our case, only short-period vertical seismometers are used, but their constants are somewhat different at the stations as Table VI shows.

Following Kirnos (Sawarenski and Kirnos 1960, p. 413) we introduce the following symbols:

$\sigma^{2}=$ Coupling factor $\left(0<\sigma^{2}<1\right)$

$\bar{\gamma}=$ Phase shift earth to registration

$\gamma_{1}=$ Phase shift earth to seismometer if $\sigma^{2}=0$

$\gamma_{2}=$ Phase shift seismometer to galvanometer if $\sigma^{2}=0$

$\gamma_{0}=\gamma_{1}+\gamma_{2}$

$h_{1}=$ Damping constant of seismometer

$h_{2}=$ Damping constant of galvanometer

$T_{e}=$ Period of earth motion

$T_{1}=$ Free period of undamped seismometer

$T_{2}=$ Free period of undamped galvanometer

$u_{1}=\frac{T_{e}}{T_{1}}$

$u_{2}=\frac{T_{e}}{T_{2}}$ 
Then we have:

$$
\tan \bar{\gamma}=(1+\delta) \tan \gamma_{0}
$$

where

$$
\begin{gathered}
\delta=n=\frac{4 h_{1} h_{2} u_{1} u_{2}}{1+u_{1}{ }^{2} u_{2}{ }^{2}-\left(u_{1}{ }^{2}+u_{2}{ }^{2}+4 h_{1} h_{2} u_{1} u_{2}\right)} \\
\tan \gamma_{1}=\frac{2 h_{1} u_{1}}{1-u_{1}{ }^{2}} \\
\tan \gamma_{2}=\frac{u_{2}{ }^{2}-1}{2 h_{2} u_{2}}
\end{gathered}
$$

In Table VI the valnes of $\gamma_{0}$ and $\Delta \gamma=\bar{\gamma}-\gamma_{0}$ if $\sigma^{2}=1$, are given. Furthermore, $\Delta t=\frac{3 / 2 \pi-\gamma_{0}}{2 \pi} . T_{\mathrm{e}}$ which gives the time difference between the phase shift $\gamma=3 / 2 \pi$, and the actual $\gamma_{0}$. The table shows, that the extreme time-lag difference between the seismograms involved in the present investigation is about $0.5 \mathrm{sec}$, and the error introduced by neglecting the value of $\sigma$ cannot exeed $0.01 \mathrm{sec}$ in the material under consideration.

No correction is made for the different phase shifts, as these are small $(<1 \%)$ compared with the time differences used in computing, the phase velocity.

\section{Phase velocity of Rayleigh waves.}

The local phase velocity of Rayleigh waves depends on the thickness of the crustal layers and the wave velocities in the crust and upper mantle.

As our intention is to evaluate the crustal thickness from observed phase velocities, we have to make some assumptions regarding the wave velocities in the crust and upper mantle. We assume no horizontal gradient of wave velocities inside each crustal layer or in the upper mantle. This is not quite true (e. g. Gutenberg 1959 a, p. 28) and may introduce some errors. The observed dispersion curves of continental Rayleigh waves differ somewhat from each other (Båth 1959) and this difference cannot be explained wholly by difference in crustal thickness. Other authors have stated that the observed continental dispersion curves show remarkably little difference (Gutenberg 1959 a, p. 44; Ewing et al 1957, p. 198). 
CRUSTAL THICKNESS IN FENNOSCANDIA, ETC.

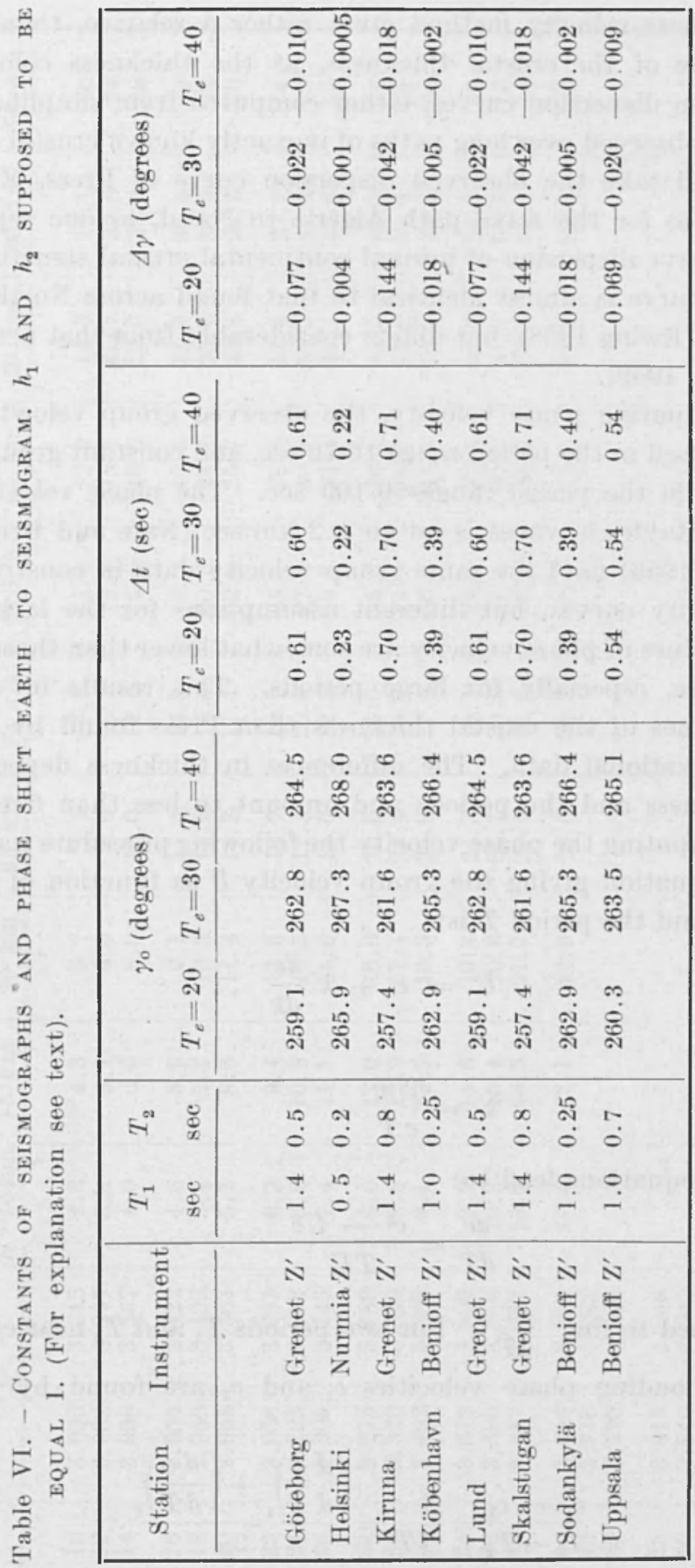


The phase-velocity method gives rather a relative, than an absolute measure of the crustal thickness, as the thickness computations are based on dispersion curves, either computed from simplified crustal models, or observed over long paths of inexactly known crustal structure.

We will take the observed dispersion curve of Press, Ewing and Oliver (1956) for the wave path Algeria to Natal, as one representing Rayleigh wave dispersion of normal continental crustal structure. This dispersion curve is almost identical to that found across North America (Oliver and Ewing 1958), but differs considerably from that across EuroAsia (Båth 1959).

In computing phase velocity, the observed group velocities across Africa are used in the period range 10-70 sec, and constant group velocity is assumed in the period range 70-100 sec. The phase velocity of 100 sec period Rayleigh waves is set to $4.2 \mathrm{~km} / \mathrm{sec}$ (Nafe and Brune 1960).

Press (1956) used the same group velocity data in constructing his phase velocity curves, but different assumptions for the lacking data.

Our values of phase velocity are somewhat lower than those computed by Press, especially for large periods. This results in somewhat smaller values of the crustal thickness than Press found by using the same observational data. The differences in thickness depend on the total thickness and the periods and amount to less than five $\mathrm{km}$.

In computing the phase velocity the following procedure was applied:

The equation giving the group velocity $U$ as function of the phase velocity $c$ and the period $T$ is:

$$
U=c+k \frac{d c}{d k}
$$

where

$$
k=\frac{2 \pi}{c T}
$$

These equations lead to:

$$
\frac{d c}{d T}=\frac{c^{2}-U c}{T U}
$$

which is used to find $\frac{\Delta c}{\Delta \bar{T}}$. For two periods $T_{1}$ and $T_{2}$ near each other, the corresponding phase velocities $c_{1}$ and $c_{2}$ are found by using the equation

$$
\frac{c_{1}-c_{2}}{T_{1}-T_{2}}=\frac{\Delta c}{\Delta T}=\frac{\left(\frac{d c}{d T}\right)_{1}+\left(\frac{d c}{d T}\right)_{2}}{2}
$$


Table VII. - Group velocity $U$ ( $H$ assumed $35 \mathrm{~km}$ ) and COMP UTED PIIASE velocity $c$ OF Rayleigh waVes aCross AFriCa. CORRESPONDING PERIODS FOR DIFFERENT CRUSTAL THICKNESS $H$.

\begin{tabular}{|c|c|c|c|c|c|c|c|c|c|c|c|c|}
\hline \multirow{2}{*}{$\begin{array}{c}T \\
\text { sec }\end{array}$} & \multirow{2}{*}{$\begin{array}{c}\delta \\
\mathrm{km} / \mathrm{sec}\end{array}$} & \multirow{2}{*}{$\begin{array}{c}c \\
\mathrm{~km} / \mathrm{sec}\end{array}$} & \multicolumn{3}{|c|}{ Period } & \multicolumn{2}{|c|}{ in $s \theta e$} & $o t h e r$ & t $t h a n$ & \multicolumn{2}{|c|}{$35 \mathrm{~km}$} & \multirow[b]{2}{*}{$70 \mathrm{~km}$} \\
\hline & & & $H=10 \mathrm{~km}$ & $15 \mathrm{~km}$ & $20 \mathrm{~km}$ & $25 \mathrm{~km}$ & $30 \mathrm{~km}$ & $40 \mathrm{~km}$ & $45 \mathrm{~km}$ & $50 \mathrm{~km}$ & $60 \mathrm{sm}$ & \\
\hline $\begin{array}{l}10 \\
12 \\
14\end{array}$ & $\begin{array}{l}3.030 \\
2.988 \\
2.968\end{array}$ & $\begin{array}{l}3.245 \\
3.297 \\
3.357\end{array}$ & $\begin{array}{l}2.8 \\
3.4 \\
4.0\end{array}$ & $\begin{array}{l}4.3 \\
5.1 \\
6.0\end{array}$ & $\begin{array}{l}5.7 \\
6.9 \\
8.0\end{array}$ & $\begin{array}{r}7.1 \\
8.6 \\
10.0\end{array}$ & $\begin{array}{r}8.6 \\
10.3 \\
12.0\end{array}$ & $\begin{array}{l}11.4 \\
13.7 \\
16.0\end{array}$ & $\begin{array}{l}12.9 \\
15.4 \\
18.0\end{array}$ & $\begin{array}{l}14.3 \\
17.1 \\
20.0\end{array}$ & $\begin{array}{l}17.1 \\
20.6 \\
24.0\end{array}$ & $\begin{array}{l}20 \\
24 \\
28\end{array}$ \\
\hline $\begin{array}{l}16 \\
18 \\
20\end{array}$ & $\begin{array}{l}2.955 \\
2.950 \\
2.965\end{array}$ & $\begin{array}{l}3.422 \\
3.492 \\
3.563\end{array}$ & $\begin{array}{l}4.6 \\
5.1 \\
5.7\end{array}$ & $\begin{array}{l}6.9 \\
7.7 \\
8.6\end{array}$ & $\begin{array}{r}9.1 \\
10.3 \\
11.4\end{array}$ & $\begin{array}{l}11.4 \\
12.9 \\
14.3\end{array}$ & $\begin{array}{l}13.7 \\
15.4 \\
17.1\end{array}$ & $\begin{array}{l}18.3 \\
20.6 \\
22.9\end{array}$ & $\begin{array}{l}20.6 \\
23.1 \\
25.7\end{array}$ & $\begin{array}{l}22.9 \\
25.7 \\
28.6\end{array}$ & $\begin{array}{l}27.4 \\
30.9 \\
34.3\end{array}$ & $\begin{array}{l}32 \\
36 \\
40\end{array}$ \\
\hline $\begin{array}{l}22 \\
24 \\
26\end{array}$ & $\begin{array}{l}3.038 \\
3.125 \\
3.208\end{array}$ & $\begin{array}{l}3.631 \\
3.692 \\
3.743\end{array}$ & $\begin{array}{l}6.3 \\
6.9 \\
7.4\end{array}$ & $\begin{array}{r}9.4 \\
10.3 \\
11.1\end{array}$ & $\begin{array}{l}12.6 \\
13.7 \\
14.9\end{array}$ & $\begin{array}{l}15.7 \\
17.1 \\
18.6\end{array}$ & $\begin{array}{l}18.9 \\
20.6 \\
22.3\end{array}$ & $\begin{array}{l}25.1 \\
27.4 \\
29.7\end{array}$ & $\begin{array}{l}28.3 \\
30.9 \\
33.4\end{array}$ & $\begin{array}{l}31.4 \\
34.3 \\
37.1\end{array}$ & $\begin{array}{l}37.7 \\
41.1 \\
44.6\end{array}$ & $\begin{array}{l}44 \\
48 \\
52\end{array}$ \\
\hline $\begin{array}{l}\mathbf{2 8} \\
30 \\
\mathbf{3 2}\end{array}$ & $\begin{array}{l}3.273 \\
3.320 \\
3.402\end{array}$ & $\begin{array}{l}3.789 \\
3.830 \\
3.866\end{array}$ & $\begin{array}{l}8.0 \\
8.6 \\
9.1\end{array}$ & $\begin{array}{l}12.0 \\
12.9 \\
13.7\end{array}$ & $\begin{array}{l}16.0 \\
17.1 \\
18.3\end{array}$ & $\begin{array}{l}20.0 \\
21.4 \\
22.9\end{array}$ & $\begin{array}{l}24.0 \\
25.7 \\
27.4\end{array}$ & $\begin{array}{l}32.0 \\
34.3 \\
36.6\end{array}$ & $\begin{array}{l}36.0 \\
38.6 \\
41.1\end{array}$ & $\begin{array}{l}40.0 \\
42.9 \\
45.7\end{array}$ & $\begin{array}{l}48.0 \\
51.4 \\
54.9\end{array}$ & $\begin{array}{l}56 \\
60 \\
64\end{array}$ \\
\hline $\begin{array}{l}34 \\
36 \\
38\end{array}$ & $\begin{array}{l}3.510 \\
3.580 \\
3.617\end{array}$ & $\begin{array}{l}3.895 \\
3.918 \\
3.937\end{array}$ & $\begin{array}{r}9.7 \\
10.3 \\
10.9\end{array}$ & $\begin{array}{l}14.6 \\
15.4 \\
16.3\end{array}$ & $\begin{array}{l}19.4 \\
20.6 \\
21.7\end{array}$ & $\begin{array}{l}24.3 \\
25.7 \\
27.1\end{array}$ & $\begin{array}{l}29.1 \\
30.9 \\
32.6\end{array}$ & $\begin{array}{l}38.9 \\
41.1 \\
43.7\end{array}$ & $\begin{array}{l}43.7 \\
46.3 \\
48.9\end{array}$ & $\begin{array}{l}48.6 \\
51.4 \\
54.3\end{array}$ & $\begin{array}{l}58.3 \\
61.7 \\
65.1\end{array}$ & $\begin{array}{l}68 \\
72 \\
76\end{array}$ \\
\hline $\begin{array}{l}40 \\
45 \\
50\end{array}$ & $\begin{array}{l}3.645 \\
3.718 \\
3.775\end{array}$ & $\begin{array}{l}3.954 \\
3.992 \\
4.022\end{array}$ & 11.4 & 17.1 & 22.9 & 28.6 & 34.3 & 45.7 & 51.4 & 57.1 & 68.6 & 80 \\
\hline $\begin{array}{l}55 \\
60 \\
65\end{array}$ & $\begin{array}{l}3.815 \\
3.846 \\
3.875\end{array}$ & $\begin{array}{l}4.046 \\
4.067 \\
4.085\end{array}$ & & & & & & & & & & \\
\hline $\begin{array}{r}70 \\
80 \\
90 \\
100\end{array}$ & $\begin{array}{l}3.887 \\
3.890 \\
3.890 \\
3.890\end{array}$ & $\begin{array}{l}4.102 \\
4.134 \\
4.167 \\
4.200\end{array}$ & & & & & & & & & & \\
\hline
\end{tabular}


The phase-velocity curve thus found is assumed to represent a crustal thickness $H$ of $35 \mathrm{~km}$, which agrees with other observations of crustal thickness in Africa (Båth 1961). Phase-velocity curves for other values of $H$ are constructed in the velocity interval $3.25<c<4.0$ $\mathrm{km} / \mathrm{sec}$ by setting $T$ proportional to $H$ (Ewing, Jardetzky and Press 1957 , chapter 4). The phas :-velocity curves thus found are given in Table VII and Fig. 12.

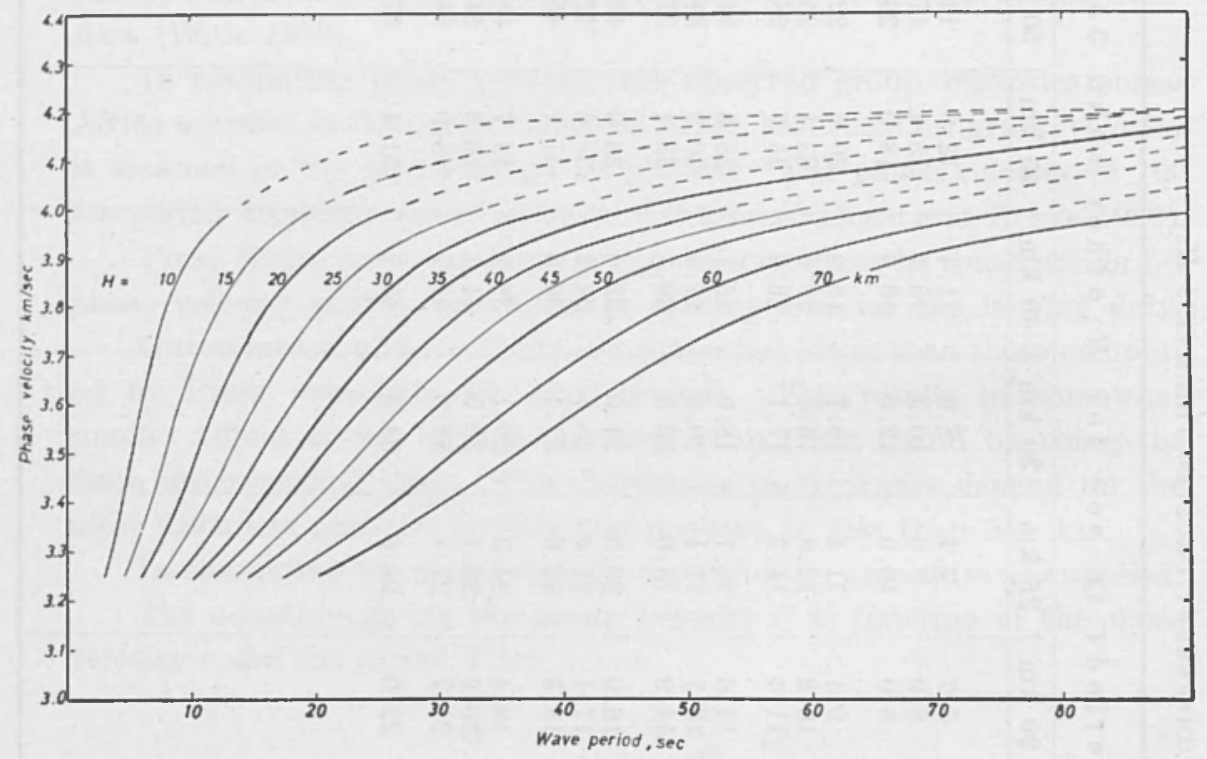

Fig. 12. - Computed phase-velocity curves for different crustal thickness.

\section{RESULT.}

The main result of this investigation is presented in Tables VIII and IX and Fig. 14. Fig. 13 shows one phase-velocity diagram for computing crustal thickness.

There is rather good agreement between the thickness values obtained from the two earthquakes, but the scatter of the individual observations is larger for the Mexico earthquake. This may be caused by lower reading accuracy of the records of the Mexico earthquake. The values given for the Kurile Islands earthquake are computed from waves $N=5-14$ (see Table III), as serious interference causes great scatter in results obtained from later waves. 
Table VIII. - Crustal thickness as compdted from phase velocity of Rayleigh waves between two stations, TAKING ACCOUNT OF DIRECTION AND CURVATURe of the WAVE Fronts. $(H=$ crustal thickness $[\mathrm{km}] ; S d=$ standard deviation of single observations; $n=$ number of observations [waves]; $\delta H=$ error in $H$ for 1 sec error in time difference).

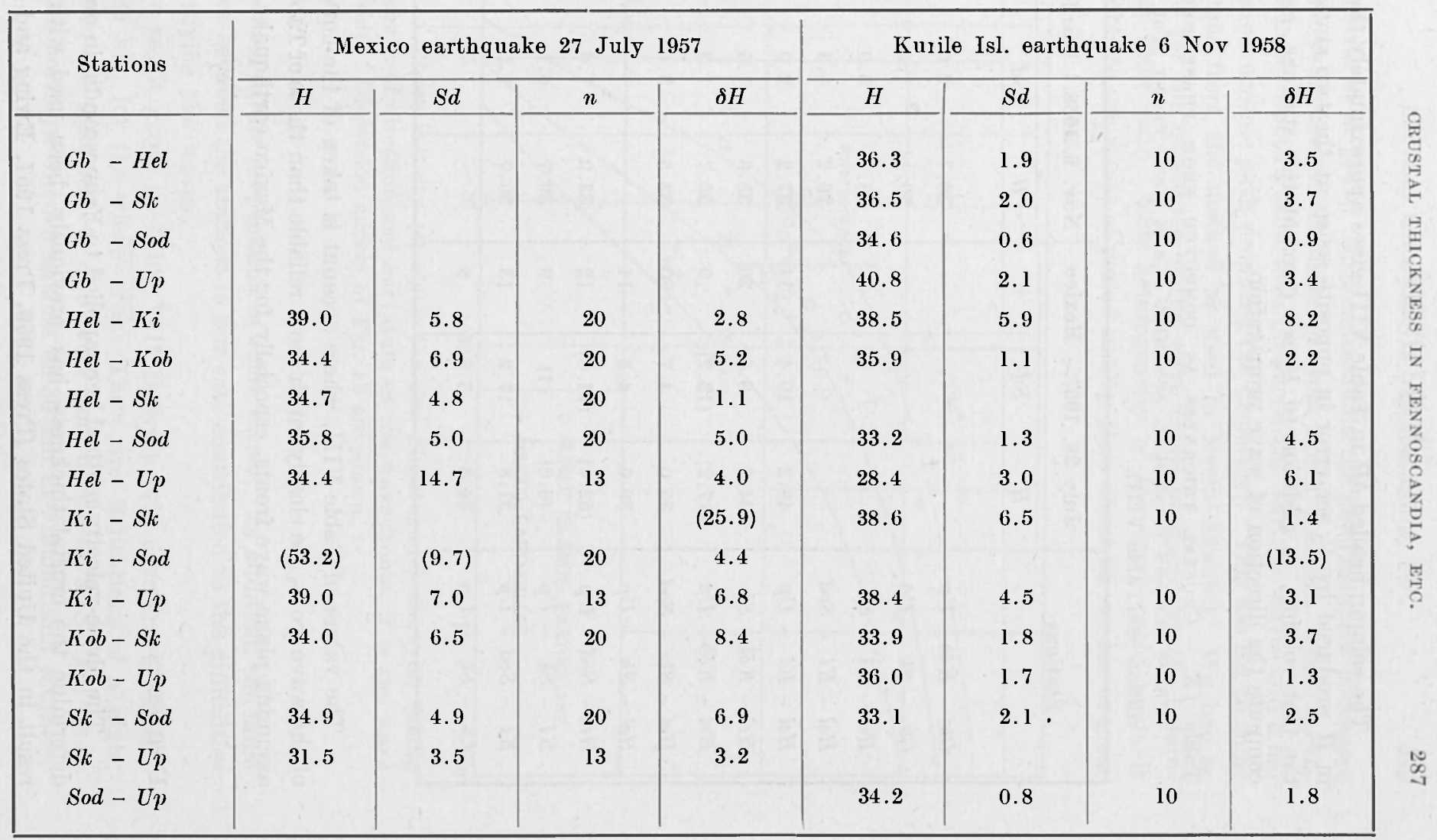


The column headed $\delta H$ in Table VIII gives approximately the error in $H$ produced by $1 / 2$ sec error in opposite sense at the two stations in the first column, in addition to $1 / 2$ sec error at the stations, used to compute the direction of wave propagation.

'Table IX. - Crustal thickness as computed from piase velocity ACROSS STATION TRIANGLes, ASSUMING PI.ANE WAVE FRONT (For explanation see Table VIII).

\begin{tabular}{|c|c|c|c|c|c|c|}
\hline \multirow{2}{*}{ Stations } & \multicolumn{3}{|c|}{ July 28, 1957 - Mexico } & \multicolumn{3}{|c|}{ Nov. 6, 1958 - Kurile Isl. } \\
\hline & $H$ & $S d$ & $n$ & $H$ & $S d$ & $n$ \\
\hline$G b-K o b-U p$ & & & & 36.7 & 2.0 & 10 \\
\hline$G b-S k-U p$ & & & & 39.1 & 1.4 & 10 \\
\hline$H e l-K i-S k$ & & & & 38.7 & 5.9 & 11 \\
\hline$H e l-K i-S o d$ & & & & 26.2 & 4.3 & 11 \\
\hline$H e l-K i-U p$ & 48.2 & 10.4 & 14 & 37.2 & 2.0 & 11 \\
\hline$H e l-K o b-S k$ & 34.6 & 6.6 & 20 & 35.6 & 1.5 & 10 \\
\hline$H e l-K o b-U p$ & $(17.2)$ & $(13.2)$ & 9 & 35.7 & 1.3 & 10 \\
\hline$H e l-S k-S o d$ & 35.0 & 4.7 & 20 & 33.5 & 3.4 & 11 \\
\hline$H e l-S k-U p$ & 36.6 & 4.5 & 14 & & & \\
\hline$H e l-S o d-U p$ & $(52.6)$ & $(14.0)$ & 12 & 33.9 & 1.6 & 11 \\
\hline$K i-S k-U p$ & $(6.6)$ & (q) & 9 & 39.7 & 6.1 & 11 \\
\hline$K i-S o d-U p$ & 31.8 & 17.2 & 13 & 30.7 & 1.6 & 11 \\
\hline$I u-S k-U p$ & 34.6 & 5.5 & 8 & & & \\
\hline
\end{tabular}

The values of Table VIII, where account is taken of the curvature of the wave front, are clearly much more reliable than those of Table IX, assuming plane wave fronts, especially for the Mexico earthquake.

\section{Discussion.}

The phase-velocity method here applied to Fennoscandia in order to determine the crustal thickness, has previously been used with good result in the United States (Press 1956, Press 1957, Ewing and Press 
1959, Oliver et al 1961). In Fennoscandia the circumstances in respect to wave paths are rather different from North America, where earthquakes in the South Pacific area produced the surface waves and a homogeneous oceanic path produced the dispersion. This has led to some deviations from the method as used in North America. We had to account for the curvature of the wave front, produced by the heterogeneous wave path. This heterogeneity of the wave paths made it impossible to use waves of period smaller than about $25 \mathrm{sec}$ due to great

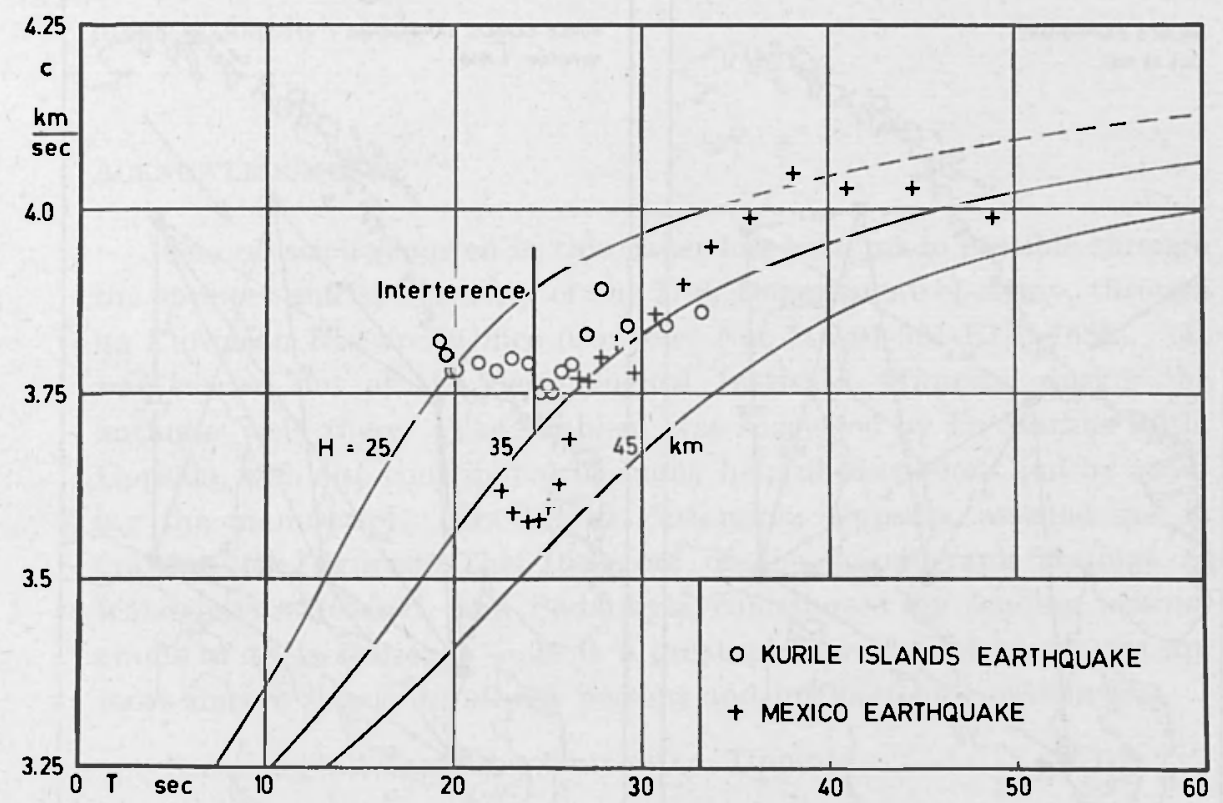

Fig. 13. - Phase velocity (c) along the line Skalstugan-Sodankylä, taking account of direction and curvature of the wave fronts. $T$ is the wave period. Dispersion curves of Fig. 12 are shown.

irregularities in the propagation of these waves. In addition, the large distances between the stations in our case contributed to the difficulties in identifying the waves.

The result given in Table VIII shows nearly constant thickness, about $35 \mathrm{~km}$, for the whole area. There are indications of a slight increase in the thickness to the west and north to $35-38 \mathrm{~km}$ as a mean for northern Sweden against 33-35 km in Finland and southern Sweden. 
As the crustal thickness is obtained from phase-velocity curves computed from group velocities measured across $A$ frica, the result must depend on the correctness of the assumptions involved. These are:

1. - Crustal thickness of Africa is $35 \mathrm{~km}$.

2. - The wave velocity and relative thickness of each layer is the same for Fennoscandia as for Africa.
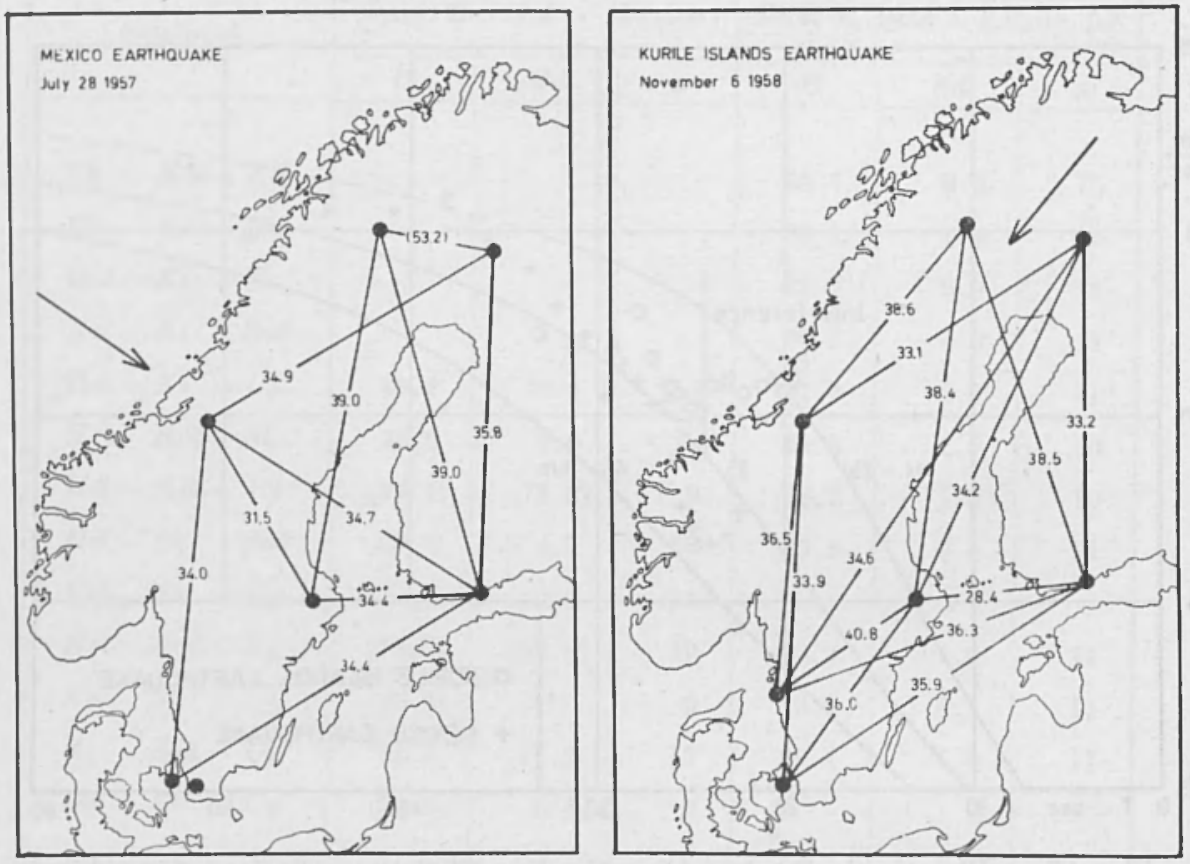

Fig. 14. - Crustal thickness in $\mathrm{km}$ as computed from phase velocity of Rayleigh waves between two stations, taking account of direction and curvature of the wave fronts.

3. - Group velocity of Rayleigh waves of period 80-100 sec is $3.890 \mathrm{~km} / \mathrm{sec}$ across Africa.

4. - Phase velocity of Rayleigh waves of 100 sec period is $4.2 \mathrm{~km} / \mathrm{sec}$.

If the result here obtained is compared with results given by other authors, the agreement is usually good. 
Porkka (1960) gives $H=34 \mathrm{~km}$ in northern Fennoscandia by using $P$ and $S$ waves from near earthquakes.

Penttilä et al (1960) found from explosion seismic methods, $H=$ $26.4-29.3 \mathrm{~km}$ decreasing westwards in south Finland. They give the thickness of the granitic layer as $18.4-21.3 \mathrm{~km}$.

Wideland (1954) has estimated the crustal thickness in Sweden from gravity data. His values as read from a diagram are: $H=23 \mathrm{~km}$ is southern Sweden, $36 \mathrm{~km}$ in central Sweden and $52 \mathrm{~km}$ in northerm Sweden. As a mean for the whole country he gives $H=30 \mathrm{~km}$ as the most probable value.

\section{ACKNOWLEDGMENTS.}

The research reported in this paper has been made possible through the support and sponsorship of the U.S. Department of Army, through its European Research Office (Contract No. DA-91-591-EUC-1637). It was carried out at the Seismological Institute, Uppsala, during the author's visit there. The problem was suggested by Dr Markus Båth, Uppsala, who also contributed by many helpful discussions and by reading the manuscript. Mrs Ingrid Pettersson, Uppsala, assisted me in drawing the figures. The Directors of the seismograph stations at Köbenhavn, Helsinki, and Sodankvlä contributed by lending seismograms of their stations. - It is a great pleasure for me to express my most sincere thanks to all the persons and institutions mentioned.

Seismological Institute, University, Uppsala

June, 1961

\section{$S U M M A R Y$}

The phase-velocity method for determination of crustal thickness is here applied to Fennoscandia. Two earthquakes were selected for the study, one in Mexico with wave propagation perpendicular to the west coast of Norway, another in the Kurile Islands with wave propagation parallel to the Norvegian coast. Because of heterogeneous wave paths the wave fronts are deformed. The actual curvature of the wave fronts was determined and taken into account in the velocity determination. The direction of the wave fronts, as determined from the arrival times at different stations, was compared with horizontal particle movements of the same waves at Firnua 
and Uppsala, and considerable deviation was found. New phase-velocity curves were calculated on base of observed group velocities across Africa. The crustal thickness in Fennoscandia was found to be nearly constant inside the area, about $35 \mathrm{~km}$.

\section{RIASSUNTO}

In questa nota viene applicato alla Fennoscandia, il metodo basato sulla velocità di fase, per la determinazione dello spessore della crosta.

Per tale studio, e allo scopo di ovviare alla deformazione dei fronti d'onda causata da tragitti eterogenei, sono stati scelti due terremoti, uno avvenuto nel Messico, con direzione di propagazione normale alla costa della Norvegia, l'altro avvenuto nelle Isole Curili, con direzione di propagazione parallela alla costa stessa. 亡̀ stata ricavata e tenuta in debito conto, nella determinazione della velocità, la curvatura dei fronti d'onda. La direzione di questi ultimi, quale è stata determinata dai tempi di arrivo nelle diverse stazioni, ̀̀ stata confrontata con $i$ movimenti orizzontali delle particelle interessate dalle stesse onde, a Kiruna e Uppsala; ̀̀ stata trovata una notevole divergenza. Le nuove curve della velocità di fase, sono state calcolate sulla base delle velocità di gruppo, osservate attraverso l'Africa. Per lo spessore della crosta in Fennoscandia, entro $i$ limiti dell'area considerata, è stato trovato un valore quasi costante di circa $35 \mathrm{~km}$.

\section{R E F E R E N C E S}

ВАти M., Seismic Surface-wave Dispersion: A World-wide Survey. "Geofisica Pura $\theta$ Applicata n, 43, 131-147, (1959).

- Die Conrad-Diskontinuität. "Freiberger Forschungshefte», C 101 (1961) (in press.).

Ewing W. M., Jardetzkx W. S. and Press F., Elastic Waves in Layered Media. McGraw-Hill (1957).

Ewing M. and Press F., Determination of Crustal Structure from Phase Velocity of Rayleigh. Waves, Part III: The United States. "Bull. Geol. Soc. Amer. n, 70, 229-244, (1959).

Gutenberg B., Physics of the Earth's Interior. Academic Press (1959 a).

- Major Earthquakes of 195\%. "Bull. Seism. Soc. Amer. ", 49, 422, (1959 b).

- Major Earthquakes of 1958. "Bull. Seism. Soc. Amer. ", 50, 323, (1960). 
NAFe J. E. and Brune J. N., Observations of Phase Velocity for Rayleigh Waves in the Period Range 100.400 Seconds. "Bull. Seism. Soc. Amer.", 50, 427-439, (1960).

Oliver J. and Ewing M. Normal Modes of Continental Surface Waves. "Bull. Seism. Soc. Amer. ", 48, 33-49, (1958).

Oliver J., Kovach R., and DorMan J., Crustal Structure of the New YorkPennsylvania Area "Journ. of Geoph. Res. ", 66, 215-225, (1961).

Penttila E., Karras M., Nurmia M., Silvola A., and Vesanen E. Report on the 1959 Explosion Seismic Investigation in Southern Finland. "Publications in Seismology, University of Helsinki, 35, 20 (1960).

Porkка M. T., On the Crustal Structure of Northern Fennoscandia as Determined from Near-Earthquake Data. "Publications in Seismology", University of Helsinki, 34, 8 (1960).

Press F., Determination of Crustal Structure from Phase Velocity of Rayleigh Waves. Part I: Southern California. "Bull. Geol. Soc. Amer.", 67, 1647-1658, (1956).

- Determination of Crustal Structure from Phase Velocity of Rayleigh Waves, Part. II: San Francisco Bay Region. "Bull. Seism. Soc. Amer.", 47, 87-88, (1957).

Press F., Ewing M. and Oliver J., Crustal Structure and Surface-Wave eDisprsion in Africa. "Bull. Seism. Soc. Amer." 46, 97-103, (1956).

Sawarenski E. F., and Kirnos D. P., Elemente der Seismologie und Seismometrie. Akademie-Verlag, (Berlin 1960).

Wideland B., Topographic - Isostatic Reduction of the Swedish Gravity Stations. "Rikets Allm. Kartverk, Medd. ", 23, 75 (Stockholm 1954). 